\title{
Effect of alcoholic beverages on progeny and reproduction of mice
}

\author{
Fernanda Dias Figueiro $^{1}$, Ana Clara Cerato Bispo ${ }^{1}$, Karla Lorena Guarido ${ }^{1}$, Priscila Marianno ${ }^{1}$, \\ Gabriel de Araújo Costa ${ }^{1}$, Helena Kaminami Morimoto², Maria José Sparça Salles ${ }^{1 *}$
}

\author{
${ }^{1}$ Department of General Biology, Londrina State University, Londrina, Paraná, Brazil, ${ }^{2}$ Department of Pathology, Clinical and \\ Toxicological Analysis, Londrina State University, Londrina, Paraná, Brazil
}

\begin{abstract}
Alcohol is the most commonly consumed substance in the world. The objective of this study was to evaluate the influence of alcoholic beverages on male reproduction and possible alterations in their offspring. The mice were divided into 4 groups: beer, wine, cachaça (a type of sugarcane rum), with ethanol concentrations of $1.9 \mathrm{~g} / \mathrm{kg}$, and control group treated with PBS. The treatment period was 35 days. The animals which received cachaça, demonstrated significant weight loss in the testes and epididymis. The alcoholic beverages promoted significant testosterone level and fertilization index diminution, and morphological alterations in the spermatozoa. The beer group presented decreased implantation sites and a high frequency of dominant lethal. The number of reabsorptions in the wine group was increased. The fermented beverages presented higher potential to induce visceral malformations, while the cachaça caused fetal skeletal malformations. The cachaça treated group presented a negative impact on semen quality and fertilization potential. The treatment with different alcoholic beverages, during spermatogenesis, demonstrated contrasting degrees of induction of toxic effects, interfering in a general aspect in male reproductive performance, fetal viability during intrauterine life, and birth defects. From the data, it is possible to infer that the distillated beverage caused more harmful effects to reproduction in this study.
\end{abstract}

Keywords: Alcoholic beverages/analysis. Wine/adverse effects. Beer/adverse effects. Cachaça/adverse effects. Reproduction/drugs effects.

\section{INTRODUCTION}

Alcohol is the most commonly consumed substance when compared with other psychoactive elements, with a world prevalence which reaches almost 2 billion consumers worldwide, attaining the "health problem" category, attributed as the cause of $3.8 \%$ of deaths and $4.6 \%$ of causes of illness worldwide, and has been singled out as an agent of more than 60 types of illness (Anderson, Chishol, Fuhr, 2009; Rehm, Mathess, Popova, 2009).

The teratogenic effects related to alcohol usage were initially described in 1968 and 1973, when a specific pattern of alcoholic mother child malformations were defined, named as fetal alcohol syndrome (Hoyme, May, Kalberg, 2005).

The majority of alcohol ingestion is metabolized by

\footnotetext{
*Correspondence: M. J. S. Salles. Universidade Estadual de Londrina, Departamento de Biologia Geral. Rodovia Celso Garcia Cid, Km 380 - Campus Universitário, P.O. box: 10.011, CEP 86057-970 - Londrina, Paraná, Brasil. Phone: 55433714527 / Fax: 5543 33714207. e-mail: salmjs00@gmail.com
}

the liver and converted to acetaldehyde. The conversion product is extremely toxic, since it can cause DNA fragmentation and therefore interfere in the cellular metabolism (Halsted, 2004).

The excessive use of alcohol is involved in hormonal, metabolic, and pathophysiological alterations, which severely influence the development and growth of offspring (Burgos et al., 2002). The decrease in serum testosterone concentration can stimulate the activity of the aromatase enzyme, present in peripheral fat cells, which is responsible for conversion of testosterone to estrogen. This substance can promote a decrease in sperm volume and density, thus influencing fertilization (Purohit, 2000).

There is insufficient knowledge on the influences of alcohol on sperm quality, which will affect the offspring. In addition, there are no studies in the literature which analyze the repercussions of different alcoholic beverages on the reproductive performance of male users and their effects on the offspring. Therefore, the objective of this study was to evaluate the influence of alcoholic beverages on male reproduction and possible alterations in their offspring. 


\section{MATERIAL AND METHODS}

All the procedures described here are in accordance with the Animal Experimentation Ethical Principles of the Brazilian Federal Veterinary Medicine Council (CFMV) and Brazilian law n. 9605 (regulated by Decree n. 3179, 21/12/1999) and were approved by the Ethics Committee on animal experimentation of the Universidade Estadual de Londrina (Londrina State University - UEL), number 8198.2013.22.

\section{Experimental design}

Male ( $n=10$ per group) and female $(n=20$ per group) Swiss mice weighing approximately 45 grams and 60 days old, sexually mature, were chosen. The animals were kept in a controlled light environment, with a 12-hour light/dark cycle, at $22 \pm 2{ }^{\circ} \mathrm{C}$, with free access to food and water. The mice were distributed equally into four experimental groups. Three groups received, via gavage, different kinds of alcoholic beverages $\left(\mathrm{G}_{1}\right)$ = beer, $\left(\mathrm{G}_{2}\right)=$ wine, and $\left(\mathrm{G}_{3}\right)=$ cachaça. Cachaça is a Brazilian beverage obtained from the fermentation of sugarcane juice (Andrade-Sobrinho et al., 2002). The ethanol concentration administrated in the groups was $1.9 \mathrm{~g} / \mathrm{kg}$ (Doremus et al., 2003). The control group $\left(G_{0}\right)$ received phosphate buffered saline (PBS). The treatment of the male mice took place on 45 consecutive days. On the $45^{\text {th }}$ day, the male mice were euthanized by cervical dislocation, and a laparotomy to remove certain organs and blood collection via cardiac puncture were performed. The collected blood was submitted to testosterone dosage via the radioimmunoassay method.

The study design included fifteen days of mating, to guarantee at least two estrous cycles of the female mice. The mating occurred on the $35^{\text {th }}$ day of male treatment, a period corresponding to a spermatogenic cycle in mice (Adler, 2000). The proportion of mating was one male to two females. The females used were not submitted to any treatment. During this period, every 12 hours, the female vaginas were examined to verify the occurrence of the "vaginal plug" which determined day zero of pregnancy. On the $18^{\text {th }}$ gestational day, the female mice were euthanized, and laparotomy and hysterectomy carried out to evaluate the uterine content.

\section{Analyzes of the male mice}

Paternal toxicity was analyzed through the weight loss, presence of piloerection, diarrhea, motor coordination, death in male mice, external analysis, and weight of the organs: lungs, kidneys, livers, testes and epididymis.

For histological procedures, the testes were fixed in Bouin solution, dehydrated at increasing alcoholic concentrations and included in paraffin (Pesce, 1987). Histological sections ( $5 \mu \mathrm{m}$ thick), were obtained by microtome and stained using the hematoxylin-eosin technique (Michalany, 1980).

The protocol of Johsen (1970) was adopted for analysis of the spermatogenesis, since it allows definition of the average result of each group. It is difficult, without this protocol, to detect changes in the spermatogenesis, since each seminiferous tubule contains germ cells in different stages of maturation. The seminiferous tubules were analyzed $(n=40)$ per animal. The histological evaluation was classified as a score from 1 to 10 . The minimum score represents the majority of the cells of the germinal line absent and few Sertoli cells in the epithelium of the seminiferous tubule. The maximum score is given when the epithelium of the seminiferous tubule exhibits all the cells that compose the spermatogenesis, including Sertoli cells.

To evaluate interstitial tissue the Leydig cells were counted and evaluated by the number of cells in a unit area $\left(\mathrm{mm}^{2}\right)$, in 10 images per animal, with a magnification of 400X.

The methodology described by Wyrobek et al. (1983) was used for the spermatozoa morphology evaluation. The spermatozoa were collected from the tails of the epididymis and 400 cells per animal were evaluated under a light microscope.

\section{Analyzes of the female mice}

Uterine content was evaluated to verify the presence of reabsorptions (embryo death), number of live and dead fetuses, and weight of the placentas. The parameters reabsorption index, post-implantation loss index, and fetal viability index were measured. The dominant lethal assay is an important method for testing mutagenic substances (Shively et al., 1984). In this context, the presence of implantation sites that develop properly in females mated with males exposed to xenobiots is used as a criterion for success in insemination and fertility (Sarkar et al., 2000). The dominant lethal assay was calculated using the formula described by Haseman, Soares (1976). The formula corresponds to 1- (average of live fetuses per pregnant female of the treated group / average of live fetuses per pregnant female of the control group x 100). This index aims to analyze the lethal dominant mutations occurring spontaneously in the control and treated groups. 


\section{Analyzes of the fetuses}

All live fetuses were weighed and measured. In addition, the weight of fetuses for pregnancy age was evaluated, according to Calderon et al. (1992). A stereoscopic microscope was used for the systemic analysis of the fetuses to detect possible external structural malformations.

For the evaluation of skeletal and visceral anomalies, half the fetuses were fixed in Bodian mixture for visceral analysis. The other half were fixed in acetone for skeletal analysis (Staples, Schnell, 1964). The visceral analysis was performed through cuts/ micro dissections as proposed by Barrow, Taylor (1969) to verify the chest and abdomen, and to evaluate the head, the strategic cuts proposed by Wilson (1965) were used. The skeletal analysis evaluated the skull, sternum, vertebrae, ribs, pelvis, collarbone, phalanges, metacarpus, and metatarsus to detect anomalies, according to the Taylor (1986) method. These evaluations were performed using a stereoscopic microscope.

\section{Statistical analysis}

The quantitative data, such as male weight gain; testosterone dosage; male organs; Johsen score; number of Sertoli cells; Leydig cells $/ \mathrm{mm}^{2}$, and parameters related to intrauterine development were analyzed by the ANOVA test followed by Tukey's test.

The qualitative data, such as fertility index; spermatozoa alterations; and skeletal and visceral malformations were analyzed by the Chi-Square test. All analyzes were performed in GraphPad Prism. The significance level adopted was $5 \%$.

\section{RESULTS}

\section{Analyzes of the male mice}

Table I presents parameters of paternal toxicity. The body weight gain was decreased in males of the $G_{1}$ and $\mathrm{G}_{3}$ compared with the $\mathrm{G}_{0}$. In relation to the organ weights there were no statistically significant data. The presence of piloerection, diarrhea, motor coordination, and deaths of male mice were not detected.

The histological testes evaluations are presented in Table II. This Table demonstrates a Johsen score reduction in the $\mathrm{G}_{1}, \mathrm{G}_{2}$, and $\mathrm{G}_{3}$ compared to $\mathrm{G}_{0}$. Concerning the Sertoli cell and Leydig cell count, there was a significant reduction in the $\mathrm{G}_{1}, \mathrm{G}_{2}$, and $\mathrm{G}_{3}$. In addition, there was a

TABLE I - Parameters related to male mice toxicity

\begin{tabular}{lcccc}
\hline Parameter & $\mathbf{G}_{\mathbf{0}}$ & $\mathbf{G}_{\mathbf{1}}$ & $\mathbf{G}_{\mathbf{2}}$ & $\mathbf{G}_{\mathbf{3}}$ \\
\hline Number of male mice & 10 & 10 & 10 & 10 \\
Weight gain[g] & $-0.554 \pm 0.669$ & $-3.201 \pm 0.595^{*}$ & $-0.850 \pm 0.799$ & $-3.2630 .531^{*}$ \\
Lung \% & 0.50 & 0.60 & 0.58 & 0.53 \\
Kidneys \% & 1.23 & 1.32 & 1.18 & 1.08 \\
Liver \% & 4.56 & 4.99 & 4.43 & 4.47 \\
\hline
\end{tabular}

Average represented data \pm SEM and relative weight (organ weight/body weight $* 100$ ). ${ }^{*} \mathrm{p}<0.5$.[ANOVA/Tukey]. $\mathrm{G}_{0}$ - Control; $\mathrm{G}_{1}$-Beer treated group with $1.9 \mathrm{~g} / \mathrm{kg}$ of ethanol; $\mathrm{G}_{2}-$ Wine treated group with $1.9 \mathrm{~g} / \mathrm{kg}$, of ethanol and $\mathrm{G}_{3}-$ Cachaça treated group with $1.9 \mathrm{~g} / \mathrm{kg}$ of ethanol.

TABLE II - Histological testes and testosterone evaluation

\begin{tabular}{|c|c|c|c|c|}
\hline$\underline{\text { Parameter }}$ & $\mathbf{G}_{0}$ & $G_{1}$ & $\mathbf{G}_{2}$ & $\mathbf{G}_{3}$ \\
\hline Number of male mice & 10 & 10 & 10 & 10 \\
\hline Score Johsen ${ }^{2}$ & 10 & $7^{*}$ & $7^{*}$ & $6^{* *}$ \\
\hline Sertoli cells ${ }^{2}$ & 15 & $12 *$ & $13 *$ & $7 * * *$ \\
\hline Leydig cell/ $\mathrm{mm}^{2}$ & 1.400 & $1.300 *$ & $1.200^{*}$ & $1.200^{*}$ \\
\hline$\underline{\text { Testosterone }[\mathrm{ng} / \mathrm{mL}]^{1}}$ & $259.5 \pm 55.68$ & $198.5 \pm 38.85^{*}$ & $183.0 \pm 49.08 *$ & $119.0 \pm 20.830^{* *}$ \\
\hline
\end{tabular}


significant reduction in the testosterone dosage in the $\mathrm{G}_{1}$, $\mathrm{G}_{2}$, and $\mathrm{G}_{3}$ in relation to $\mathrm{G}_{0}$.

The male mice spermatozoa morphology evaluations are presented in Table III. Anomalous spermatozoa were found in all groups, presenting tail and head alterations. The $\mathrm{G}_{1}, \mathrm{G}_{2}$, and $\mathrm{G}_{3}$ demonstrated statistically significant alterations when compared to $\mathrm{G}_{0}$. Furthermore, the G3 males presented testicle and epididymis weight reduction.

Table IV shows the male mice reproductive performance. The treated groups presented a reduction in the number of fertile animals, being significant in the $\mathrm{G}_{3}$.

\section{Analyzes of the female mice}

Parameters related to the intrauterine progeny development are presented in Table $\mathrm{V}$. The $\mathrm{G}_{1}$ demonstrated a reduced number of implantations and live fetuses, when compared to $G_{0}$. The $G_{2}$ presented a higher number of reabsorptions and consequently a rise in the reabsorption index and post-implantation loss, these parameters being statistically significant. The LPF (Lethal Prevalent Frequency) (\%) analysis demonstrates that all groups treated with the alcoholic beverages demonstrated prevalent lethal induced mutations, statistically significant in the $G_{1}$ group which showed high mutation indices.

\section{Analyzes of the fetuses}

Table VI presents analyses of the fetuses. The weight and length of fetuses were not statistically significant. In total, 397 fetuses were analyzed and no external congenital malformations were found. In the skeletal analysis the following malformations were found: Sternum, interparietal, and supraoccipital. The malformations in the $\mathrm{G}_{3}$ were statistically significant. Concerning the visceral analysis, the $G_{1}$ and $G_{2}$ showed statistically significant alterations in the heart, such as reduced myocardium and sponge appearance.

\section{DISCUSSION}

The ingestion of alcohol may induce impotence, infertility, and alterations in functions of male reproductive organs (Emanuele, Emanuele, 2000). There are different alcoholic drinks, based on the production process, through which the beverage is prepared by distillation or fermentation processes, in addition to differences in the raw material from which the beverage is produced, such as barley, grapes, and sugarcane.

In the toxicological analyses, negative weight gain was observed. This weight loss can be justified by the effects of alcohol on the metabolism as, when used chronically, alcohol potentiates the Mitochondrial System of Oxidation of Ethanol (SMOE), which occurs on the cytochrome p-450 system. SMOE increases the thermogenic potential of food, thus increasing the basal metabolism rate in alcoholics (Suter, Hasler, Vetter, 1997).

The Johsen score showed the spermatogenesis

TABLE III - Male mice testes, epididymis, and spermatozoa morphological evaluation

\begin{tabular}{lcccc}
\hline Percentage & $\mathbf{G}_{\mathbf{0}}$ & $\mathbf{G}_{\mathbf{1}}$ & $\mathbf{G}_{\mathbf{2}}$ & $\mathbf{G}_{\mathbf{3}}$ \\
\hline Number of male mice & 10 & 10 & 10 & 10 \\
${\text { Testes }{ }^{1}}^{1}$ & 0.47 & 0.45 & 0.44 & $0.39^{*}$ \\
Epididymis $\%^{1}$ & 0.25 & 0.28 & 0.24 & $0.18^{* * *}$ \\
Spermatozoa with tail alterations $^{2}$ & 16.8 & $19.75^{* * *}$ & $27.35^{* * *}$ & $21.55^{* * *}$ \\
Spermatozoa with head alterations $^{2}$ & 1.7 & $2.95^{* * *}$ & $16.25^{* * *}$ & $3.9^{* * *}$ \\
\hline
\end{tabular}

${ }^{*} \mathrm{p}<0.5$ and $^{* * *} p<0.001{ }^{1}$ Average represented relative weight (organ weight/body weight $\left.{ }^{*} 100\right)$ [ANOVA/Tukey]. ${ }^{2}$ [Chi-square test]. $\mathrm{G}_{0}$ - Control; $\mathrm{G}_{1}$-Beer treated group with $1.9 \mathrm{~g} / \mathrm{kg}$ of ethanol; $\mathrm{G}_{2}$ - Wine treated group with $1.9 \mathrm{~g} / \mathrm{kg}$ of ethanol and $\mathrm{G}_{3}-\mathrm{Cachaça}$ treated group with $1.9 \mathrm{~g} / \mathrm{kg}$ of ethanol.

TABLE IV - Parameters related to the male mice reproductive performance

\begin{tabular}{lcccc}
\hline Parameter & $\mathbf{G}_{\mathbf{0}}$ & $\mathbf{G}_{1}$ & $\mathbf{G}_{2}$ & $\mathbf{G}_{3}$ \\
\hline Fertile males/number of paired males & $10 / 10$ & $8 / 10$ & $7 / 10$ & $5 / 10^{*}$ \\
Pregnant females/number of paired females & $20 / 20$ & $14 / 20^{* *}$ & $12 / 20^{* *}$ & $9 / 20^{* *}$ \\
Fertility index [\%] & 100 & 80 & 70 & $50^{*}$ \\
\hline
\end{tabular}

${ }^{*} \mathrm{p}<0.5$ and ${ }^{* *} \mathrm{p}<0.01$. [Chi-square test]. $\mathrm{G}_{0}$ - Control; $\mathrm{G}_{1}$-Beer treated group with $1.9 \mathrm{~g} / \mathrm{kg}$ of ethanol; $\mathrm{G}_{2}-$ Wine treated group with $1.9 \mathrm{~g} / \mathrm{kg}$ of ethanol and $\mathrm{G}_{3}-$ Cachaça treated group with $1.9 \mathrm{~g} / \mathrm{kg}$ of ethanol. 
TABLE V - Parameters related to the intrauterine progeny development

\begin{tabular}{|c|c|c|c|c|}
\hline Parameter & $\mathrm{G}_{0}$ & $\mathrm{G}_{1}$ & $\mathrm{G}_{2}$ & $\mathrm{G}_{3}$ \\
\hline Number of female mice & 20 & 14 & 12 & 9 \\
\hline Implantations number & $11.230 \pm 2.618$ & $7.916 \pm 3.528^{*}$ & $11.250 \pm 2.187$ & $11.250 \pm 2.187$ \\
\hline Live fetuses number & $10.307 \pm 2.287$ & $7.166 \pm 2.979^{*}$ & $9.875 \pm 1.457$ & $10.125 \pm 2.587$ \\
\hline Reabsorption number & $0.846 \pm 0.800$ & $0.833 \pm 1.193$ & $2.125 \pm 1.125^{*}$ & $0.875 \pm 0.479$ \\
\hline Reabsorption index & $7.059 \pm 5.407$ & $8.300 \pm 3.244$ & $13.983 \pm 9.739^{*}$ & $8.515 \pm 5.323$ \\
\hline Post-implantation loss & $7.609 \pm 7.495$ & $6.912 \pm 3.244$ & $13.983 \pm 9.739^{*}$ & $10.546 \pm 5.165$ \\
\hline Fetal viability & $92.390 \pm 5.767$ & $93.087 \pm 3.244$ & $86.016 \pm 9.739$ & $89.450 \pm 5.165$ \\
\hline Placental individual weight $[\mathrm{g}]$ & $0.106 \pm 0.009$ & $0.111 \pm 0.011$ & $0.101 \pm 0.006$ & $0.112 \pm 0.006$ \\
\hline Placental index & $0.078 \pm 0.023$ & $0.082 \pm 0.007$ & $0.070 \pm 0.003$ & $0.079 \pm 0.004$ \\
\hline $\begin{array}{l}\text { Evaluation of the weight of fetuses for } \\
\text { pregnancy age }\end{array}$ & ---- & WFAPA $^{1}$ & WFAPA $^{1}$ & WFAPA $^{1}$ \\
\hline Frequency of dominant lethal & ---- & $20.76 \%{ }^{*}$ & $4.19 \%$ & $1.76 \%$ \\
\hline
\end{tabular}

Average represented data \pm SEM. ${ }^{*} \mathrm{p}<0.5 . \mathrm{G}_{0}$ - Control; $\mathrm{G}_{1}$-Beer treated group with $1.9 \mathrm{~g} / \mathrm{kg}$ of ethanol; $\mathrm{G}_{2}-$ Wine treated group with $1.9 \mathrm{~g} / \mathrm{kg}$ of ethanol and $\mathrm{G}_{3}-$ Cachaça treated group with $1.9 \mathrm{~g} / \mathrm{kg}$ of ethanol. ${ }^{1} \mathrm{WFAPA}=$ Weight of fetuses was adequate for pregnancy age.

TABLE VI - Analyses of fetuses

\begin{tabular}{|c|c|c|c|c|c|}
\hline & $\mathrm{G}_{0}$ & $\mathrm{G}_{1}$ & $\mathrm{G}_{2}$ & $\mathrm{G}_{3}$ \\
\hline \multicolumn{2}{|c|}{ Total number of fetuses } & 126 & 98 & 76 & 97 \\
\hline \multicolumn{2}{|c|}{ Individual fetal weight $[\mathrm{g}]^{1}$} & $1.372 \pm 0.032$ & $1.344 \pm 0.055$ & $1.430 \pm 0.021$ & $1.419 \pm 0.030$ \\
\hline \multicolumn{2}{|l|}{ Fetal length $[\mathrm{cm}]^{1}$} & $2.762 \pm 0.047$ & $2.711 \pm 0.060$ & $2.664 \pm 0.054$ & $2.716 \pm 0.071$ \\
\hline & & $\mathrm{G}_{0}$ & $\mathrm{G}_{1}$ & $\mathrm{G}_{2}$ & $\mathrm{G}_{3}$ \\
\hline \multirow{7}{*}{$\begin{array}{l}\text { Skeletal } \\
\text { Malformations } 2\end{array}$} & Number of analyzed fetuses & 66 & 53 & 40 & 51 \\
\hline & Number of normal fetuses & 57 & 46 & 33 & 33 \\
\hline & Total number of malformed fetuses & 9 & 7 & 7 & 18 \\
\hline & Sternum malformation & 5 & 5 & 5 & 9 \\
\hline & Interparietal malformation & 2 & 1 & 1 & 4 \\
\hline & Supraoccipital malformation & 2 & 1 & 1 & 5 \\
\hline & $\% \mathrm{MF}$ & 13.6 & 13.2 & 17.5 & $35.29^{* *}$ \\
\hline \multirow{6}{*}{$\begin{array}{l}\text { Visceral } \\
\text { Malformations }{ }^{2}\end{array}$} & Number of analyzed fetuses & 60 & 45 & 36 & 46 \\
\hline & Number of normal fetuses & 60 & 38 & 32 & 45 \\
\hline & Total number of malformed fetuses & 0 & 9 & 4 & 1 \\
\hline & Reduced Myocardium & 0 & 6 & 3 & 1 \\
\hline & Sponge Appearance of Myocardium & 0 & 3 & 1 & 0 \\
\hline & $\% \mathrm{MF}$ & 0 & $19.14^{* * *}$ & $11.1^{*}$ & 2.17 \\
\hline
\end{tabular}

${ }^{*} \mathrm{p}<0.5 .^{* *} \mathrm{p}<0.01$ and $\mathrm{o}^{* * *} \mathrm{p}<0.001 . \mathrm{G}_{0}$ - Control; $\mathrm{G}_{1}$-Beer treated group with $1.9 \mathrm{~g} / \mathrm{kg}$ of ethanol; $\mathrm{G}_{2}-$ Wine treated group with $1.9 \mathrm{~g} / \mathrm{kg}$ of ethanol and $\mathrm{G}_{3}-$ Cachaça treated group with $1.9 \mathrm{~g} / \mathrm{kg}$ of ethanol. ${ }^{1}$ Average represented data $\pm \mathrm{SEM}$ [ANOVA/Tukey].

2\%MF: malformation percentage [Chi-square test].

were immature in all treated groups. Many studies have evidenced that germ cells are the target of ethanol toxicity, and this agent can promote damage during the production of spermatozoa and differentiation of spermatozoa. The alcohol can act directly on the testes, which may decrease dosages of some hormones responsible for germinal maturation and reduce the nutrition that Sertoli cells provide to germ cells. (Raychoudhury, Flowers, Millette, 2000).

The number of Sertoli cells was reduced in all treated groups. These cells have important functions in the 
spermatogenesis: mechanical support, germ cell nutrition and movement, paracrine regulation, phagocytosis, steroid hormones synthesis, and spermiation. The Sertoli cells are susceptible to the action of numerous toxic substances, presenting morphological and functional alterations, induced by xenobiotics (Hess, Nakai, 2000).

The alcohol negatively affected the activity of Leydig cells, compromising the production of testosterone, which is responsible for the development and maturation of germ cells. The testosterone dosage reduced in all treated groups, in addition to which the number of Leydig cells decreased. Testosterone is synthesized from cholesterol by a sequence of enzymatic chains within the Leydig cells (Rosenblatt et al., 2010). This can infer there is evidence of a degenerative testicular process considering the Johsen score and decrease in testosterone, suggesting a negative impact on semen quality and fertility potential.

The morphological analysis of spermatozoa contained in the epididymis presented tail and head alterations. According to Villata, Ballesca, Nicolás (1997) stated that fertility disturbance is related to ethanol ingestion, besides which it can promote low spermatozoa concentration with damage to mobility and raise the teratozoospermia number (Gomathi, Balasubramanian, Vijayabanu, 1993). These alterations can compromise motility, and consequently fecundation. These changes associated with chromosomal mutation can wreck the embryo implantation by natural selection (George, Gramath, Johansson, 2006).

There was a reduction in the average weights of the testes and epididymis in the treated groups. According to Basth, Oko, (1989) testes and epididymis weight reductions can induce important functional variations, compromising the spermatozoa morphology, considering that spermatogenesis starts in the seminiferous tubules, the formed spermatozoa migrate to the epididymis, where they mature and are stored. Gonçalves et al. (2017) showed that the number of abnormal seminiferous tubules increased in ethanol drinking rats.

In the female analyses, the high frequency of dominant lethal were presented in the $\mathrm{G}_{1}$. This suggests that beer may promote mutations in germ line cells present in the testicles. According to Leber (1988) these genes do not compromise fertilization but interfere with the normal development of the embryo resulting in lethality in the early stages prior to implantation. This statement justifies the lower number of implanted and live fetuses observed in this group.

The $\mathrm{G}_{2}$ favored the abortion of fetuses in more advanced development phases, evidenced by the rise in reabsorption numbers, reabsorption index, and post- implantation loss. The $\mathrm{G}_{3}$ did not show a statistically significant result related to fetal viability during the intrauterine life. This demonstrates that the fetuses that crossed the barrier of all or nothing were able to overcome the intrauterine development, but still presented a higher index of skeletal malformations. The fetuses which were exposed to fermented beverages presented higher visceral malformations.

It can be concluded that treatment of male mice with different types of alcoholic beverages induced different degrees of toxic effects, compromising the male mice reproductive performance, fetal viability during the intrauterine life, and congenital malformations (birth defects). Among the malefic effects mentioned, the distillated beverage caused more damage to reproduction, when compared to the other beverages tested in this study.

\section{REFERENCES}

Adler ID. Spermatogenesis and mutagenicity of environmental hazards: extrapolation of genetic risk from mouse to man. Andrologia.2000;32(4-5):233-7.

Anderson P, Chishol D, Fuhr DC. Effectiveness and costeffectiveness of policies and programmes to reduce the harm caused by alcohol. Lancet. 2009;373(9682):2234-46.

Andrade-Sobrinho LG, Boscolo M, Lima-Neto BS, Franco DW. Carbamato de etila em bebidas alcoólicas (cachaça, tiquira, uísque e grapa). Quím Nova. 2002;25(6):1074-7.

Barrow MV, Taylor WJ. A rapid method for detecting malformations in rat fetuses. J Morphol. 1969;127(3):291-306.

Basth AD, Oko RJ. Abnormal morphology of bovine spermatozoa. Ames: Iowa State University Press; 1989. 285 p.

Burgos MGPA, Medeiros MC, Bion FM, Pessoa DCNP. Efeitos de bebidas alcóolicas em mães lactantes e suas repercussões na prole. Rev Bras Saúde Matern Infant. 2002;2(2):129-35.

Calderon IMP, Rudge MVC, Brasil MAM, Henry MACA. Modelo experimental em ratas para estudo do binômio diabete e gravidez. Acta Cir Bras. 1992;7(4):136-44.

Doremus TL, Brunell SC, Varlinskaya EI, Spear LP. Anxiogenic effects during withdrawal from acute ethanolin adolescent and adult rats. Pharmacol, Biochem Behav. 2003;75(2):411-8.

Emanuele MA, Emanuele N. Alcohol and the male reproductive system. Alcohol Res Health. 2000;25:282-7. 
George L, Granath F, Johansson AL. Risks of repeated miscarriage. Paediatr Perinat Epidemiol. 2006;20(2):119-26.

Gomathi C, Balasubramanian K, Vijayabanu N. Effects of chronic alcoholism on some studies on lipid profiles. J Androl.1993;16(3):175-81.

Gonçalves DG, Vieira AN, Vieira HR; Valério AD, Siervo GEML, Pinheiro PFF, Martinez FE, Guarnier FA, Teixeira GR, Fernandes GSA. Role of resistance physical exercise in preventing testicular damage caused by chronic ethanol consumption in UChB rats. Microsc Res Tech. 2017;80(4):37886.

Halsted CHMD. Nutrition and alcoholism liver disease. Sem Liver. 2004;3:289-304.

Haseman JK, Soares ER. The distribuition of fetal death in control mice and its implication on statistical tests for dominant lethal effects. Mutat Res. 1976;73:133-42.

Hess RA, Nakai M. Histopathology of the male reproductive system induced by the fungicide benomyl. Histol Histopathol.2000;15(1):207-24.

Hoyme HE, May PA, Kalberg WO. A practical approach to diagnosis of fetal alcohol spectrum disorders: clarification of the 1996 Institute of Medicine criteria. Pediatrics. 2005;115(1):3947.

Johsen SG. Testicular biopsy score countra method for registration of spermatogenesis in human testes: normal values and results in 335 hypogonadalmals. Hormones. 1970;303:2-25.

Leber AP. Chemical induction of dominant lethal mutations in mammals. In: Allantyne B, editor. Perspectives in basic and applied toxicology. London: John Wrigth; 1988. p. 199-205.

Michalany J. Técnica histológica em anatomia patológica: com instruções para o cirurgião, enfermeira e citotécnico. São Paulo: EPU; 1980. Operações fundamentais da técnica histológica; p.22-31.

Pesce CM. The testicular biopsy in the evaluation of male infertility. Sem Diagn Pathol.1987:4(4):264-74.

Purohit V. Can alcohol promote aromatization of androgens to estrogens? a review. Alcohol. 2000:22(3):123-7.
Raychoudhury SS, Flowers AF, Millette CF. Toxic effects of polychlorinated biphenyls on cultured rat Sertoli cells. J Androl. 2000;21(6):964-73.

Rehm J, Mathers C, Popova S. Global burden of disease and injury and economic cost attributable to alcohol use and alcoholuse disorders. Lancet. 2009;373(9682):2223-33.

Rosenblatt C, Delgado Filho MA, Delgado DR, Delgado FR. infertilidade masculina - novos conceitos. Urologia 2010;71:8592

Sarkar M, Gangopadhyay P, Basak B, Chakrabarty K, Banerji J, Adhikary P. Chatterjee A. The reversible anti- fertility effect of Piper betle Linn on Swiss albino male mice. Contraception. 2000;62(5):271-4.

Shively CA, White DM, Blauch JL, Tarka Jr SM. Dominant lethal testing of theobromine in rats. Toxicol Lett. 1984;20(3):325-9.

Staples RE, Schnell VL. Refinements in rapid clearing technic in the $\mathrm{KOH}$-alizarin red $\mathrm{S}$ method for fetal bone. Stain Technol. 1964;39:61-3.

Suter PM, Hasler E, Vetter W. Effects of alcohol on energy metabolism and body weight regulation: is alcohol a risk factor for obesity? Nutr Rev. 1997;55(5):157-71.

Taylor P. Skeletal examination. In: Practical teratology. London: Academic Press; 1986. p.77-100.

Villata J, Ballesca JL, Nicolás JM. Testicular function in asymptomatic chronicalcoholism: relation to ethanol intake. Alcohol Clin Exp Res. 1997;21(1):128-33.

Wilson JG. Methods for administering agents and detecting malformations in experimental animals. In: Teratology: principles and techniques. Chicago: University of Chicago Press; 1965. p.262-77.

Wyrobek AJ, Gordon LA, Burkhart JG, Francis MW, Kapp RW $\mathrm{Jr}$, Letz G, et al. An evaluation of the mouse sperm morphology test and other sperm tests in non-human mammals: a report of the US. Environmental Protection Agency. Amsterdam: GeneTox Program; 1983. p.1-72.

Received for publication on $14^{\text {th }}$ March 2017 Accepted for publication on $07^{\text {th }}$ August 2017 